\title{
Study on the Way to Realize the Function of Network Culture in Higher Education
}

\author{
Chunming $\mathrm{Xu}^{1}$, Can Wang ${ }^{2, *}$, Nan Yang ${ }^{3}$ \\ ${ }^{1}$ Student Development and Services Office, Dalian University of Science and Technology, Dalian, Liaoning 116052, \\ China \\ ${ }^{2}$ School of Digital Technology, Dalian University of Science and Technology, Dalian, Liaoning 116052, China \\ ${ }^{3}$ School of Economics and Management, Dalian University of Science and Technology, Dalian, Liaoning 116052, China \\ ${ }^{*}$ Corresponding author.Email: 652196979@qq.com
}

\begin{abstract}
With the advent of the new media era, new media has penetrated into every aspect of college students' study and life, bringing opportunities and challenges to college education. Colleges and universities should take the initiative to occupy the position of network culture education, fully explore the positive role of new media on campus, and better realize the function of network culture education by persisting in leading the consciousness, improving the management system, enhancing the awareness of trends and developing new media on campus.
\end{abstract}

Keywords: University, new media, network culture, education function

\section{INTRODUCTION}

As an indispensable social communication channel in today's society, with the rapid development and wide application of Internet technology, profound changes are taking place in education and teaching in various fields, including colleges and universities. Campus network culture is the product of the combination of campus culture and network culture. The innovation of network information technology and the popularization of more and more intelligent teaching equipment on campus make campus network culture gradually present the characteristics of the times, such as rapidity, diversity and interaction. In the new period, it is very important to give full play to the educational function of campus network culture in the work of improving the training quality and comprehensive quality of young college students[1]. Therefore, colleges and universities should make good use of new media and new technologies so that education and teaching can be carried out flexibly, vividly and vividly.

\section{THE CHALLENGE OF NETWORK CULTURE COMMUNICATION TO COLLEGE EDUCATION}

With the continuous development and innovation of network technology and network carrying media, network culture changes with each passing day. Network culture is an emerging cultural form that integrates and delays traditional culture based on technology and integrates different groups and environments. With the integration of network and education, the spread of network culture is bound to have a profound impact on ideological and political education in colleges and universities. Changing teachers' educational content and methods will also bring new changes to students' learning paths and ideological cultivation.

\subsection{Network Culture Into the Classroom Will Be a New Way of Ideological and Political Education in Colleges and Universities}

The development of network is the result of scientific research on information technology, so network culture is also the product of information culture. Under the background of "Internet plus", ideological and political education in colleges and universities will gradually combine with the information technology platform, and at the same time, it is necessary to face up to the profound cultural influence of network culture[2]. Education itself is the continuation and transmission of a kind of culture, and the network culture also relies on the media to develop in the form of digitization and informatization. Today, when the Internet is integrated into daily life, network culture affects everyone's way of thinking and behavior. Therefore, ideological and political education in colleges and universities will actively integrate network culture into classroom teaching. In many colleges and universities in the classroom, the active part of the network culture in college ideological instruction class, such as the patriotism thought in the course of conduct, reasonable application platform, network culture to watch the patriotic video at the same time, guide students in the QQ group, group WeChat, weibo platform for discussion and interaction, at the same time of improving students' learning autonomy, deepen students content to connect. By taking advantage 
of the liveliness and variability of positive network language, we can improve students' discourse power in learning and increase the effective interaction between teachers and students. With the innovation and development of ideological and political education in colleges and universities, the future network culture into the classroom is bound to open a broader situation.

\subsection{The Integration of Network Culture into Practice Will Be the Due Meaning of Ideological and Political Studies for College Students}

College students' ideological and political study should pay attention to the combination of classroom study and after-class practice. Because of the high frequency of college students' use of network platforms, the influence of network culture on after-class practice will gradually increase with the development of The Times. Network culture will enter the online practice of ideological and political education in colleges and universities, and realize the extension and expansion of traditional culture, morality and education depending on the carrier of network culture. For example, the platform of network community is used to build study groups, actively develop collective wisdom, spread and publicize excellent network culture, and practice socialist core values. At the same time of understanding the textbook knowledge, combining network technology, virtual reality experience is added to after-class comprehension activities, so that students can have a deeper understanding of the textbook knowledge and improve their enthusiasm for learning. With the improvement of WeChat, weibo,app and other network platforms, college students will make use of fragmented time to study and deepen their thoughts after class, watch and understand the spirit contained in the outstanding model deeds[3]. On this basis, the author draws lessons from the practice methods and paths of social dedication, further comprehends the culture and thought learned on the network in the concrete practice, and achieves the deepening and development of personality. In addition, I will combine the construction of campus network culture platform with the activities organized by the community, so as to increase my knowledge in the community activities, understand the charm of excellent network culture, and apply what I have learned in class.

\section{THE MECHANISM OF NETWORK CULTURE'S EDUCATIONAL FUNCTION}

In a sense, whether it is the cognition of the external environment or the way of thinking of the knowledge system, the network culture has a great impact on young college students, making their lives richer and broader. Their world view, outlook on life and values are also influenced by it. Excellent network culture can promote teachers and students to quickly form a common code of conduct and the pursuit of life, so as to enhance the campus cohesion and centripetal force. When carrying out the education and teaching of various subjects, colleges and universities, relying on the network and new media technology, gradually integrate text, sound and video into the mainstream culture of the campus, and embody its scientific nature, nationality and flexibility incisively and vividly[4].

\section{REALIZATION OF NETWORK CULTURE EDUCATION FUNCTION}

\subsection{Leading the Construction of Campus Network Culture With Advanced Socialist Culture}

Another important task in teaching and educating students in colleges and universities is to guide young college students to actively practice socialist core values and carry forward the fine traditional culture of the Chinese nation and the advanced socialist culture. So the construction of excellent campus network culture, one is to adhere to the direction of the development of socialist advanced culture, the ideological content and the vitality, the combination of new era around xi the ideas of socialism with Chinese characteristics into the campus, the plait content such as text, video, audio, with students' favorite WeChat, weibo, trill, micro view, learning power, micro party class, the little red book, such as network form, singing the main melody of today's society, culture, spread the positive energy, armed with advanced ideology and culture students' mind; Second, we should integrate socialist core values into the construction of campus network culture, inherit the excellent traditional Chinese culture and advanced socialist culture, and create a campus network culture[5]. For example, with the help of new media on campus, we can learn about current politics, world affairs, district and city conditions, good stories in the region, and good stories on campus. We can actively guide young college students to set up correct values, which can not only supplement the main classroom channels and enrich teaching resources, but also realize the full coverage of campus education and teaching both online and offline.

\subsection{Strengthen the Construction of Campus Network Culture With Excellent Talents}

First of all, Internet culture is both interactive and open. Young college students can correctly use the Internet to accept new ideas and perceive positive energy, which is inseparable from the careful education and guidance of college teachers. Colleges and universities to build a match the network culture construction and management of teachers' team, technical development team and guide the team, then continue to strengthen the construction of 
campus network culture of leadership, such as learning through training, improve teachers' and students' ideological consciousness, national culture, enrich the professional theory knowledge such as mental health education, really positive guidance and education are silent. Secondly, it is necessary for the school to regularly grasp the ideological trends of young college students. By carrying out network activities with rich contents, introducing topics of interest to students, carrying out targeted online questionnaire survey on students' ideology, comprehensively grasping the ideological trends of college students and timely grasping the initiative of ideological and political education.

In addition, the school should also set up high-quality student backbone team to train them to participate in the construction of campus network culture. Focus on training students who have certain writing skills and love new media management. Relying on, coming from, and caring for students, we will actively guide young college students to become active practitioners of maintaining the order of the Internet and building a good network morality. We can also cultivate a group of campus Internet celebrities full of positive energy by digging out good stories on campus, developing web celebrity columns, and propagandize advanced typical deeds, so as to infect and encourage students to share thumb up actively, so as to achieve spiritual and emotional resonance.

To sum up, only by forming a three-in-one construction team of "teacher-students-campus network celebrity", can we better guarantee the education function of campus network culture[6].

\subsection{Realize Various Educational Functions of Campus Network Culture Through Perfect System Guarantee}

In order to effectively realize the campus network education function and provide a safe and effective guarantee for the network environment, colleges and universities should establish and improve the management, operation and supervision system of new media.

First of all, colleges and universities should build a new media communication matrix according to the actual conditions such as campus scale, structure and faculty, and define the functions and responsibilities of each post, so as to ensure the authoritative information source and regular information update of campus network culture, so as to constantly regulate the operation of new media platforms on campus.

Secondly, colleges and universities should establish a network management system with unified command, online and offline control, so as to pool the positive energy of moral cultivation. First, we should further strengthen the school's network ideology work by relying on the campus new media platform and insisting on the scientific and standardized management. Second, we should combine the management of campus network culture with education and teaching, and the self-discipline of young college students with other disciplines, so as to speed up the construction of campus network order jointly completed by school supervision, organization supervision and college students' self-discipline.

\section{OPTIMIZATION OF NETWORK CULTURE EDUCATION FUNCTION IN COLLEGES AND UNIVERSITIES}

\subsection{Create a Good Ecology and Enhance the Awareness of the Trend of Campus Network Culture Construction}

Campus network culture should give full play to the ideological guidance of college students and the role of mainstream culture in cohesion and cohesion. By innovating campus network cultural products, a series of network contents popular with young college students, such as patriotism and struggle, should be carried out and guided by firm ideals and beliefs.

In the era of "Internet plus", young college students are the promoters and acceptors of network culture. They take the initiative to acquire the ideological culture through the network. Therefore, only by grasping and applying the new media, new technologies and other fashionable elements, can campus network culture better play the function of spreading mainstream ideology and culture. In terms of form, it keeps innovating, and USES micro video, animation, mind mapping and other methods to produce new products with content guided by mainstream thoughts. In terms of content, it summarizes and sorts out the copywriting of the current "hot articles" on the Internet, and focuses on the campus situation to tell good stories and spread the good voice of the campus. In terms of theme, we will turn the truth into a content that is popular with students with tolerance and temperature, so as to create a more vivid, three-dimensional and vivid campus network culture landscape.

\subsection{Create Network Brand Culture and Create a Strong Campus Network Culture Atmosphere by Holding College Students' Network Culture Festival}

Depending on the official micro blog and official website, push the theme class meeting, theme education, knowledge contest, impression photographing, resource saving series of activities, as well as the rich and colorful selection activities such as civilized dormitory, civilized class and civilized office, etc., the teachers and students' fine conduct can be illuminated in every detail. 


\subsection{Join Various Media Development Platforms for Coordinated Development}

Campus network culture is an important channel for contemporary young college students to acquire ideology and culture, and has gradually become an important carrier of education. With the development of mobile Internet, big data, cloud computing, etc., in the process of national education reform and development, mainstream media in colleges and universities are also competing for media integration, which provides a soil for the reform and innovation of new media in colleges and universities. Campus network media should actively accept and adapt to the current situation of integrating media development, promote the efficient integration of integrating media development and campus education and teaching, and further enhance the timeliness and infectivity of university education. The big data shows that when the campus network culture plays its role in educating students, the media platforms it mainly relies on have various ways of expression, and the operation situation and the focus group are relatively stable. However, the effect of educating students is not well highlighted and the resultant force of collaborative educating students is insufficient. Therefore, in the process of network culture communication in colleges and universities, it is necessary to constantly strengthen the group attention, network culture education effect and network culture institution setting in order to give full play to the network culture education function in colleges and universities.

To realize the function of campus network culture education is the only way for colleges and universities to improve the quality of student training under the new situation. Excellent campus network culture construction, strengthen the ideological and moral construction of the campus network culture, creating high quality young college students the spirit of new homes, build online lesson, the three-dimensional network of classroom education interactive space, in the campus network culture to establish $\mathrm{a}$ is to guide the speech, service between teachers and students, promote the vital Qi, to carry out the important position of socialist core values education, and it is also continuously deepening the reform of higher education, improve the quality of personnel training in colleges and universities and education level of realistic need.

\section{CONCLUSION}

Under the new situation, the establishment of the network literacy for ideological education development is increasingly important, mesoscopic present network language violence, copycat phenomenon, a network review all reflect the network users literacy cultivation problems, as the biggest use network group, college students should pay attention to the improvement of network literacy, so as to avoid being confused by the impact of the network environment. Meanwhile, ideological and political education teachers in colleges and universities should follow closely the changes of students and improve their own network literacy, so as to optimize the effect of ideological and political education. First of all, both teachers and students should be firm in their ideals and beliefs. Teachers should stick to professional ethics, guide students to stand firm in the "waves" of the Internet, judge the right and wrong of information, and maintain and adhere to the correct outlook on life and values. Students should also think well, follow the footsteps of the teacher, study Marx and Engels classic theory, understand the central policy. Secondly, both teachers and students should cultivate correct network awareness, and teachers should actively develop new models and methods of network ideological and political teaching, and screen excellent network culture into classroom teaching. Students should strengthen the study of marxist thought, improve the ideological level and theoretical level, so that the moral consciousness of network culture internalized in the heart. At the same time, teachers should also improve the ability to use network culture and network education software, touch the hearts of college students and be good at inducing, supplement classroom teaching, and give play to the hidden value of ideological and political education.

\section{REFERENCES}

[1] The CPC central committee and the state council, Opinions on strengthening and improving ideological and political work in universities under the new situation, People's Daily, 2017.

[2] $\mathrm{Fu}$ Baoqian, Building a harmonious campus network culture, Times economic and trade, 2007.

[3] Xia Shouxin, Han Junhua, Innovative application of new network media in ideological and political education of college students, School party building and ideological education, 2018, pp. 62-64.

[4] Gao Chundi, Shen Ziyou, Lin Zitao, Research on the educational function of campus network culture, Educational observation (first half month), 2016, pp.1113.

[5] Li Mei, Value implication and practice path of lide shuren, Teaching and management, 2019.

[6] Shi Guoliang, The strategic requirements for the implementation of the fundamental task of morality shuren in the new era, China higher education, 2018. 